\title{
An Embarrassing Predicament
}

Doug Gilroy

WHEN I began my hobby of nature photography, one of my first subjects was a fellow who bears the fancy latin name of "Miphitis hudsonica", but in plain ordinary English it means "Prairie Skunk".

One of these striped kittens had a habit of visiting a certain slough in the early hours of the day where he picked up a few luscious morsels for dessert before retiring for the day. So it was that I took up my camera and set out in the hopes of obtaining a fine kodachrome of this little gentleman (?).

Sure enough, there he was trotting along beside the fence, just leaving the slough. It was a beautiful peaceful morning and the little skunk looked quite innocent and harmless. However, as I approached him, he began to hurry a little faster and his bushy tail began to stand straight up, with the long hairs standing out like a Fuller brush. This, I knew, meant he was no innocent youngster. He carried a gun and it was loaded for action.

I scouted around in front of him, not too hurriedly, in an attempt not to alarm him and yet head him off from the direction of the valley where he was going. He was a determined little cuss and had no notion of changing his course. "Alright," thought I "I'll just stand in your way and let you come right up to me. As long as you keep your artillery pointed the other way I've nothing to worry about."

On he came, and I chuckled gleefully to myself at how easily I was going to get his picture. When about four feet away from me he stopped and stamped his feet angrily while I began to focus my camera. At that very second the little crook let go with a "block buster". The air that was so sweet and pure suddenly became so thick and vile that it was enough to blind a man. I felt a liquid running down my cheeks and off my chin. The little brute must have put a curve on it-or was it a slight breeze that blew the spray my way? At any rate I was shot right in the head.

This was a very embarrassing condition to go around in, so I sneaked back to the barn-just like any dog would do-and there I got an idea. Pouring out a liberal amount of gasoline in a basin, I washed my face thoroughly in it. This was followed by a shave.

After that treatment no one made any remarks regarding my fragrance -well, not very many anyway.

\section{The Hazelcliffe Fisher H. M. Rayner}

M OST interesting to me of all items in the last BLUE JAY was the note from Hazelcliffe about the killing of a fisher in the Qu'Appelle Valley. Has it been verified whether this was a wild animal or an escapat from a fur farm? If the former, it is really a remarkable record tc find a fisher, an animal of the wilderness, so deep in settled country.

As a youth in the opening years of the century I did some hunting and trapping myself. My mentor in woodcraft ways was a veteran trapper who had spent his life in the wilderness on trail and trapline. I remembered asking him once if he had evel seen a fisher running alive. His face lit up with a vivid memory. "Only once," he said, "just once, many year's ago, I saw one. He was gallopiry, with his back arched and his great tail streaming out behind a rare sight, boy, a rare sight!"

\section{Howard the Crane Succumbs}

GAN ANTONIO, Tex., Nov. 22, (AP). - Howard the whooping crane died of a gunshot wound.

His death makes another gap in the vanishing flock of 32 , the only known whooping cranes in the world.

Howard came from the far north Nov. 3 to spend the winter on a sun-bathed island in the Gulf of Mexico near Corpus Christi, Tex.

Managel Julian Howard of the Arkansas wildlife refuge noticed he dragged a leg in flight. Later manager Howard found Howard on the ground, unable to stand. One of his pipe-stem legs had been broken by a bullet.

\section{Put To Bed}

Last Saturday, Howard the crane was put to bed in a crate of hay and taken to the San Antonio zoo for treatment. Howard failed to respond to treatment. 